\title{
Kualitas Pelayanan Pemasangan Listrik Prabayar Pada PT. PLN (Persero) Area Pelayanan Banyumanik
}

\author{
Dini Setyorini \\ Universitas Bina Sarana Informatika \\ email : dini.die@bsi.ac.id

\begin{tabular}{ccc} 
Diterima & Direvisi & Disetujui \\
$22-02-2019$ & $20-09-2019$ & $24-09-2019$ \\
\hline
\end{tabular}

\begin{abstract}
Abstrak - Tidak dapat dihindarkan bahwa saat ini layanan publik menjadi perhatian publik. Layanan publik biasa datang dari lembaga yang melayani kebutuhan orang banyak. Dalam pelaksanaan pelayanan memerlukan dukungan sumber daya yang baik, yaitu karyawan yang dapat diandalkan dan siap atau mampu bekerja dan juga alat pendukung lainnya termasuk sistem atau kebijakan di perusahaan itu. Penelitian ini bertujuan untuk mengetahui kualitas layanan untuk pemasangan listrik prabayar di PT. PLN (Persero) wilayah layanan Banyumanik Semarang. Analisis data yang digunakan adalah skor interpretasi (IS) yang diperoleh dari responden. Responden berjumlah 80 orang menggunakan purposive sampling. Sedangkan untuk menyelesaikan penelitian ini, penulis juga menggunakan data sekunder yang diperoleh dari berbagai sumber yang ada. Berdasarkan hasil penelitian yang dilakukan dapat disimpulkan bahwa dimensi yang menunjukkan kualitas layanan meliputi bukti fisik (bukti langsung), keandalan, daya tanggap, jaminan dan empati menunjukkan interpretasi yang kuat di mana pelanggan merasa puas dengan kualitas layanan PT. PLN (Persero) wilayah layanan Banyumanik Semarang.
\end{abstract}

Kata Kunci : Kualitas, pelayanan, kepuasan

\begin{abstract}
It cannot be denied that at present the public service is a concern of the public. Ordinary public service come from agencies that serve the community for the needs of every community. Implementation of services requires the support of human resources, namely employees who are reliable and ready or able to work and supporting tools including the system. This study aims to determine quality of service for prepaid electricity installation at PT. PLN (Persero) Banyumanik Semarang service area. Analysis of the data used is a score interpretation (IS) obtained from respondents. Respondents numbered 80 people using purposive sampling. While to complete this research, the author also uses secondary data obtained from various existing sources. Based on the results of the research conducted it can be concluded that the dimensions that show service quality include tangibles ( direct evidence), reliability, responsiveness, assurance and emphaty show a strong interpretation where customers feel satisfied with the quality service of PT. PLN (Persero) Banyumanik Semarang service area.
\end{abstract}

Keywords : quality; service; satisfaction

\section{PENDAHULUAN}

Tidak dapat dipungkiri bahwa di masa sekarang ini pelayanan publik menjadi perhatian masyarakat. Pelayanan publik biasa berasal dari instansi yang melayani masyarakat untuk keperluan yang dibutuhkan setiap masyarakat. Di sektor publik ada tiga fungsi pelayanan yang dilakukan pemerintah yaitu : environmental service, protective service, dan development service. Pelayanan oleh pemerintah dibedakan berdasarkan siapa yang menerima layanan tersebut, apakah pihak individu atau pihak kelompok. (Markoni, 2015) Sebagai perusahaan penyedia jasa, PT PLN (Persero) sudah seharusnya mengedepankan kualitas pelayanan yang baik, seperti penyediaan fasilitas fisik, perlengkapan, pegawai dan sarana komunikasi. PT. PLN (Persero) sebagai perusahaan penyediaan jasa listrik merupakan perusahaan Badan Usaha Milik Negara sehingga dituntut memberikan pelayanan yang baik sebagai good governence. Pada bagian area pelayanan, ada petugas yang berhubungan langsung dengan konsumen atau pelanggan yang dituntut untuk memberikan pelayanan prima baik dari sisi komunikasi, penampilan, penguasaan informasi tentang listrik, menerima keluhan serta mencari jalan keluar dari setiap permasalahan yang ada. 
Pelaksanaan pelayanan memerlukan dukungan Sumber Daya Manusia (SDM), yaitu pegawai atau karyawan yang handal dan siap, maksudnya pegawai yang mampu menguasai apa yang dikerjakan juga mampu mengoperasikan segala alat pendukung maupun sistemnya. Hal ini disebabkan pegawai atau karyawan tersebut yang akan melaksanakan pelayanan, terutama ketika berhadapan langsung dengan konsumen atau masyarakat. Oleh karena itu kualitas Sumber Daya Manusia (SDM) para pegawai yang ada di kantor perlu ditingkatkan. Salah satu cara untuk meningkatkan kualitas pelayanan para pegawai adalah para pegawai diberikan arahan dan training mengenai pentingnya pelayanan. Karena pelayanan prima merupakan upaya untuk memberikan rasa puas dan menumbuhkan kepercayaan terhadap pelanggan atau customer.

Manajemen kualitas merupakan aspek dari seluruh fungsi manajemen yang menetapkan dan melaksanakan kebijakan kualitas. Faktor utama yang menunjang keberhasilan kebijakan kualitas adalah kesadaran tentang kualitas bagi para anggota perusahaan / organisasi. Di dalam manajemen kualitas, tanggung jawab ada pada pimpinan puncak, dan agar pelaksanaan dapat efektif, diperlukan partisipasi dan kerjasama dari semua anggota perusahaan, sejak dari tingkat operator sampai ke pimpinan perusahaan, dan meliputi seluruh bagian / departemen yang ada di dalam perusahaan, seperti bagian produksi, pemasaran, keuangan, dan lainlainnya. ( Edy Sutrisno, 2015)

Namun demikian data empiris menunjukkan masih banyak keluhan dari masyarakat terkait pelayanan dari PT. PLN (Persero) mengenai pelayanan publik ini. Oleh karena itu yang menjadi masalah utama dalam penelitian ini adalah melihat faktor apa saja yang paling mempengaruhi kepuasan pelanggan terhadap pelayanan publik.

\section{METODOLOGI PENELITIAN}

Penelitian ini bertujuan untuk mengukur kualitas pelayanan pemasangan listrik prabayar dan bagaimana tingkat kepuasan pelanggan ketika proses pemasangan listrik prabayar. Objek penelitian ini dibatasi hanya pada pelanggan prabayar PT PLN (Persero) Area Banyumanik Semarang. Desain riset dalam penelitian ini menggunakan metode survey. Data primer diperoleh langsung dari responden terpilih dengan membagikan daftar pertanyaan terstruktur. Adapun responden dalam penelitian ini adalah pelanggan PT PLN (Persero) Area Banyumanik Semarang, yang menggunakan listrik Prabayar. Sedangkan untuk melengkapi penelitian ini, penulis juga menggunakan data sekunder yang diperoleh dari berbagai sumber yang ada. Populasi dalam penelitian ini adalah seluruh pelanggan PT
PLN (Persero) Area Banyumanik Semarang yang telah mendapatkan pelayanan dalam pemasangan listrik Prabayar baru dari Januari 2017 sampai dengan Desember 2018 yaitu sebanyak 8011 pelanggan. Adapun jumlah sampel (sampling size) yang digunakan dalam penelitian sebanyak 80 responden, dengan menggunakan rumus Slovin. Karena keterbatasan dana, tenaga, dan waktu, maka penulis menggunakan Purposive Sampling.

Purposing Sampling adalah sampel yang diambil dari populasi dilakukan secara sengaja atau menunjuk langsung kepada orang yang dianggap dapat mewakili karakteristik-karakteristik populasi. (Pasolong 2012) Pengumpulan data dilakukan melalui wawancara (interview), berdasarkan daftar pertanyaan yang telah disiapkan. Daftar pertanyaan yang diajukan menggunakan skala likert. Pertanyaan yang diajukan bersifat pertanyaan tertutup. Penelitian ini menggunakan kualitatif deskriptif sebagai alat analisis. Alat analisis dalam penelitian ini menggunakan perhitungan Interpretasi Skor (IS). Untuk menghitung skor dari skala likert tersebut menjadi angka persentase, digunakan Distribusi Frekuensi Relatif. Frekuensi relatif (angka persentase) menggunakan rumus (Sudijono, 2012) :

$P=f / N \times 100 \%$

Keterangan:

$\mathrm{f}=$ Jumlah Jawaban

$\mathrm{N}=$ Jumlah frekuensi/banyaknya responden

$\mathrm{P}=$ Angka persentase Sedangkan untuk mendapatkan persentase kepuasan maka digunakan rumus sebagai berikut :

Persentase jawaban $=$ Total skor yang di dapat $/$ skor maksimal x $100 \%$

Tabel 1. Dasar Intrepretasi Skor Item

\begin{tabular}{|l|l|l|}
\hline No & Skor / Angka & Intepretasi \\
\hline 1 & $0 \%-20 \%$ & $\begin{array}{l}\text { Sangat } \\
\text { Rendah }\end{array}$ \\
\hline 2 & $21 \%-40 \%$ & Rendah \\
\hline 3 & $41 \%-60 \%$ & Cukup \\
\hline 4 & $61 \%-80 \%$ & Kuat \\
\hline 5 & $81 \%-100 \%$ & Sangat Kuat \\
\hline
\end{tabular}

\section{HASIL DAN PEMBAHASAN}

Pelayanan sebuah perusahaan sangat tergantung dari sumber daya manusia. Kepribadian sumber daya manusia sangat menentukan pelayanan sebuah perusahaan tersebut. Kepribadian adalah keseluruhan bentuk atau cara dimana seseorang bereaksi dan berinteraksi dengan orang lain. (Robbins dalam Achmad Sudiro, 2018) Kepribadian membentuk perilaku setiap individu. Kepribadian ini sangat mempengaruhi perilaku seseorang dalam organisasi. 
Dalam organisasi ada standardisasi pelayanan yang diterapkan. Standardisasi adalah proses merumuskan, merevisi, menetapkan, dan menerapkan standar, dilaksanakan secara tertib dan atas kerjasama dengan semua pihak. Sedangkan standar didefinisikan sebagai spesifikasi teknis atau sesuatu yang dibakukan, disusun berdasarkan konsensus semua pihak yang terkait dengan memperhatikan syarat-syarat kesehatan, keselamatan, perkembangan ilmu pengetahuan dan teknologi, serta pengalaman, perkembangan masa kini dan masa yang akan datang, untuk memperoleh manfaat yang sebesar-besarnya. (Edy Sutrisno, 2015) Menurut Parasuraman (1990) yang merupakan penyempurnaan dari penelitian khusus terhadap beberapa jenis kualitas pelayanan yang ekselen dan menghasilkan lima dimensi pokok kualitas jasa adalah sebagai berikut :

1. Tangibles (bukti langsung), yaitu meliputi fasilitas fisik dan jasa, perlengkapan atau peralatan yang dipergunakan, pegawai dan sarana komunikasi atau representasi fisik dari jasa misalnya peralatan yang dipakai untuk mengkonsumsi jasa tersebut seperti sambungan telepon. Segala bukti fisik seperti pegawai, fasilitas, peralatan, tampilan fisik dari pelayananmisalnya kartu kredit plastik. Menurut Parasuraman, Zeithaml, \& Berry yaitu segala bukti fisik seperti pegawai, fasilitas, peralatan, tampilan fisik dari pelayanan Dengan demikian bukti langsung/wujud merupakan satu indikator yang paling konkrit. Wujudnya berupa tampilan pegawai, segala fasilitas yang secara nyata dapat terlihat. Kenyataan di lapangan dari tampilan para pegawai sangat menunjukkan bahwa tampilan sebagai petugas pelayanan yang professional, baik pendapat dari para responden (pelanggan) yang berpendapat para pegawai berpenampilan sopan, dan juga rapi dalam melayani. Berdasarkan observasi dan narasumber juga berpendapat bahwa segala yang diberikan kepada pelanggan apalagi dalam proses pelayanan selau memberikan yang terbaik apa lagi dari segi tampilan dan fasilitas. Sesuai

2. Reliability (kehandalan), kemampuan memberikan pelayanan yang diberikan dengan segera, akurat dan memuaskan. Dari lima dimensi ini, faktor ini merupakan yang paling penting dari kualitas pelayanan. Determinan ini mencakup 2 hal pokok yaitu konsistensi kerja (performance) dan kemampuan dipercaya (dependability). Berarti perusahaan harus memberikan jasanya secara tepat sejak pertama (right the first time) sesuai dengan skedul pelayanan yang disepakati.

3. Responsiveness (daya tanggap), yaitu keinginan para staf untuk membantu para pelanggan dan memberikan pelayanan dengan tanggap meliputi kecepatan, kompetensi, kenyamanan, mudah direparasi, serta penanganan keluhan yang memuaskan sejak proses penjualan hingga purna jualnya (service ability).

4. Assurance (jaminan), mencakup pengetahuan, kemampuan, kesopanan dan sifat dapat dipercaya yang dimiliki para staf perusahaan, bebas dari bahaya, resiko atau keragu raguan, termasuk kualitas jasa yang dipersepsikan oleh pelanggan dari citra dan reputasi produk serta tanggung jawab perusahaan terhadapnya (perceived quality).

5. Emphaty (empati), meliputi kemudahan dalam melakukan hubungan, komunikasi yang baik, perhatian perusahaan kepada pribadi pelanggan dan memahami kebutuhan para pelanggan. Esensi dimensi ini adalah menyampaikan pelayanan melalui sentuhan pribadi atau yang berorientasi pada keinginan pelanggan yang unik dan spesifik.

Berikut adalah hasil survey kuesioner mengenai pelayanan pemasangan listrik prabayar pada PT. PLN (Persero) Area Pelayanan Banyumanik Semarang :

\section{Dimensi Tangibles (bukti langsung)}

Dari hasil survey dan wawancara terhadap pelanggan PT. PLN (Persero) Area Pelayanan Semarang Banyumanik bahwa dari sektor tangibles dilihat dari sisi penampilan karyawan lapangan (seragam yang rapi, bersih dan sopan), kualitas meter listrik pintar yang terpasang, dan kelengkapan peralatan dalam pemasangan listrik prabayar, hasil menunjukkan sangat kuat yaitu berada di skor $85 \%$ sesuai dengan tabel yang digambarkan di bawah ini :

Tabel 2. Dimensi Bukti Langsung

\begin{tabular}{|l|l|l|}
\hline No & Pernyataan IS & Penangan : \\
\hline 1 & $\begin{array}{l}\text { Penampilan lapangan karyawan : } \\
\text { seragam yang rapi, bersih dan } \\
\text { sopan }\end{array}$ & $\begin{array}{l}\text { Kualitas Meter Listrik Pintar } \\
\text { MLP) yang dipasang } \\
\text { merupakan kualitas yang baik }\end{array}$ \\
\hline 3 & $\begin{array}{l}\text { Kelengkapan peralatan dalam } \\
\text { pemasangan listrik prabayar }\end{array}$ & $88,29 \%$ \\
\hline
\end{tabular}

Sumber : Data primer diolah (2018)

Dari tabel 2 dapat dilihat penampilan lapangan karyawan memiliki intrepretasi skor 79,99\%, kualitas meter listrik pintar yang dipasang memiliki intrepretasi skor $82,16 \%$, kelengkapan peralatan dalam pemasangan listrik prabayar memiliki intrepretasi skor $88,29 \%$.

\section{Dimensi Reliability (kehandalan)}

Ada enam kriteria yang diajukan kepada responden untuk menjawab pertanyaan untuk menilai dimensi kehandalan yaitu meliputi : kehandalan petugas dalam memasang listrik prabayar, proses pemasangan listrik prabayar sangat baik dan cepat, apakah petugas telah memberikan pelayanan yang baik sesuai yang dibutuhkan, keterampilan petugas 
dalam pemasangan listrik, apakah petugas tepat waktu dalam pemasangan listrik, apakah proses pemasangan listrik sangat cepat dan mudah. Dari hasil survey tersebut didapat intrepretasi yang kuat pada kualitas pelayanan PT. PLN (Persero) Area Pelayanan Banyumanik Semarang, hal itu dapat dilihat pada tabel berikut :

Tabel 3. Dimensi Kehandalan

\begin{tabular}{|l|l|l|}
\hline No & Pernyataan IS & \\
\hline 1 & $\begin{array}{l}\text { Kehandalan petugas dalam } \\
\text { pemasangan listrik Prabayar }\end{array}$ & $82,42 \%$ \\
\hline 2 & $\begin{array}{l}\text { Proses pemasangan listrik } \\
\text { prabayar yang dilakukan oleh } \\
\text { petugas sangat baik dan cepat }\end{array}$ & $77,86 \%$ \\
\hline 3 & $\begin{array}{l}\text { Petugas sudah memberikan } \\
\text { pelayanan yang baik sesuai } \\
\text { dengan yang Anda butuhkan }\end{array}$ & $70,12 \%$ \\
\hline 4 & $\begin{array}{l}\text { Keterampilan petugas dalam } \\
\text { pemasangan listrik prabayar }\end{array}$ & $78,88 \%$ \\
\hline 5 & $\begin{array}{l}\text { Petugas tepat waktu dalam } \\
\text { pemasangan listrik Prabayar }\end{array}$ & $70,28 \%$ \\
\hline 6 & $\begin{array}{l}\text { Proses pemasangan listrik } \\
\text { Prabayar sangat mudah dan } \\
\text { cepat 73,18\% }\end{array}$ & \\
\hline
\end{tabular}

Sumber : Data primer diolah (2018)

Dari tabel 3 dapat dilihat kehandalan petugas dalam pemasangan listrik prabayar memiliki intrepretasi skor $82,42 \%$, kecepatan dan kebaikan yang dilakukan petugas dalam proses pemasangan listrik prabayar memiliki intrepretasi skor $77,86 \%$, pelayanan sesuai dengan kebutuhan kita atau tidak memiliki intrepretasi skor 70,12\%, keterampilan petugas dalam pemasangan listrik prabayar memiliki intrepretasi skor $78,88 \%$, ketepatan waktu petugas dalam pemasangan listrik prabayar memiliki intrepretasi skor 70,28\%, kemudahan dan kecepatan proses pemasangan listrik prabayar memiliki intrepretasi skor $73,18 \%$.

\section{Dimensi Responsiveness (Daya Tanggap)}

Berdasarkan hasil penelitian, dimensi responsiveness (Daya Tanggap) meliputi informasi yang jelas dan mudah dimengerti oleh petugas, petugas pemasangan listrik yang cepat dalam melayani, informasi mengenai pemasangan listrik prabayar yang mudah di dapat dan jelas, petugas yang bersedia menolong ketika mengalami kesulitan dalam menggunakan listrik prabayar, dan petugas pelayanan listrik prabayar tidak menunjukkan kesan sibuk ketika melayani, diduga memiliki hasil yang kuat berdasarkan survey terhadap konsumen. Berikut data tabel intrepretasi :
Tabel 4. Dimensi Daya Tanggap

\begin{tabular}{|l|l|l|}
\hline No & Pernyataan & IS \\
\hline 1 & $\begin{array}{l}\text { Petugas memberikan informasi yang } \\
\text { jelas dan mudah dimengerti mengenai } \\
\text { listrik prabayar }\end{array}$ & $80,75 \%$ \\
\hline 2 & $\begin{array}{l}\text { Petugas pemasangan listrik prabayar } \\
\text { cepat dalam melayani }\end{array}$ & $74,33 \%$ \\
\hline 3 & $\begin{array}{l}\text { Informasi mengenai listrik prabayar } \\
\text { mudah di dapat dan jelas }\end{array}$ & $81,00 \%$ \\
\hline 5 & $\begin{array}{l}\text { Petugas bersedia menolong ketika kita } \\
\text { mengalami kesulitan dalam } \\
\text { menggunakan listrik prabayar }\end{array}$ & $66,86 \%$ \\
\hline 5 & $\begin{array}{l}\text { Petugas pemasangan listrik prabayar } \\
\text { tidak kelihatan sibuk sendiri ketika } \\
\text { melayani Anda }\end{array}$ & $73,28 \%$ \\
\hline
\end{tabular}

Sumber : Data primer diolah (2018)

Dari tabel 4 dapat kita lihat bahwa petugas memberikan informasi yang jelas dan mudah dimengerti mengenai listrik prabayar memiliki intrepretasi skor $80,75 \%$, kecepatan dalam melayani pemasangan listrik prabayar oleh petugas memiliki intrepretasi skor $74,33 \%$, kejelasan dan kemudahan informasi mengenai listrik prabayar memiliki intrepretasi skor 81,00\%, kesediaan petugas menolong ketika kita mengalami kesulitan dalam menggunakan listrik prabayar memiliki intrepretasi skor $66,86 \%$, serta perhatian petugas pemasangan listrik prabayar dalam melayani memiliki intrepretasi skor $73,28 \%$.

\section{Dimensi Assurance (Jaminan)}

Berdasarkan hasil penelitian, dimensi assurance (jaminan) yang meliputi : senyum yang diberikan oleh petugas, petugas bersikap sopan dan menghormati pelanggan, petugas bersikap jujur (tidak meminta bayaran / tips), dan petugas memberikan penjelasan mengenai penggunaan listrik prabayar yang aman dan benar, diduga memiliki intrepretasi yang sangat kuat. Hal tersebut dapat dilihat dari tabel di bawah ini :

Tabel 5. Dimensi Jaminan

\begin{tabular}{|l|l|l|}
\hline No & Pernyataan & IS \\
\hline 1 & $\begin{array}{l}\text { Petugas selalu memberikan } \\
\text { senyum }\end{array}$ & $82,89 \%$ \\
\hline 2 & $\begin{array}{l}\text { Petugas bersikap sopan dan } \\
\text { menghormati pelanggan }\end{array}$ & $81,76 \%$ \\
\hline 3 & $\begin{array}{l}\text { Petugas bersikap jujur (tidak } \\
\text { meminta bayaran / tips) }\end{array}$ & $88,12 \%$ \\
\hline 4 & $\begin{array}{l}\text { Petugas memberikan penjelasan } \\
\text { menggunakan listrik prabayar } \\
\text { dengan aman dan benar }\end{array}$ & $81,10 \%$ \\
\hline
\end{tabular}

Sumber : Data primer diolah (2018)

Dari tabel 5 dapat dilihat bahwa apakah petugas selalu memberikan senyum memiliki intrepretasi skor $82,89 \%$, petugas bersikap sopan dan menghormati pelanggan memiliki intrepretasi skor $81,76 \%$, petugas bersikap jujur memiliki intrepretasi 
skor $88,12 \%$, petugas memberikan penjelasan menggunakan listrik prabayar dengan aman dan benar memiliki intrepretasi skor $81,10 \%$.

\section{Dimensi Emphaty (Empati)}

Berdasarkan hasil penelitian, dimensi emphaty (empati) yang meliputi petugas memberikan perhatian dalam menggunakan listrik prabayar (petugas memberikan tutorial singkat), petugas bersikap ramah dan sopan, kemampuan komunikasi petugas dalam proses pemasangan listrik prabayar, petugas tidak memandang status sosial pelanggan sehingga memberikan pelayanan yang optimal, petugas memberikan kesempatan bertanya kepada pelanggan seusai pemasangan listrik prabayar, diduga memiliki hasil yang kuat. Hal ini dapat dilihat pada tabel di bawah ini :

Tabel 6. Dimensi Empati

\begin{tabular}{|l|l|l|}
\hline No & Pernyataan & IS \\
\hline 1 & $\begin{array}{l}\text { Petugas memberikan perhatian } \\
\text { dalam menggunakan listrik prabayar } \\
\text { (memberikan tutorial singkat) }\end{array}$ & $65,13 \%$ \\
\hline 2 & $\begin{array}{l}\text { Petugas bersikap ramah dan sopan } \\
\text { Kemampuan komunikasi petugas } \\
\text { dalam proses pemasangan listrik } \\
\text { prabayar }\end{array}$ & $71,25 \%$ \\
\hline 4 & $\begin{array}{l}\text { Petugas tidak memandang status } \\
\text { sosial pelanggan, sehingga } \\
\text { memberikan pelayanan optimal } \\
\text { kepada pelanggan }\end{array}$ & \\
\hline 5 & $\begin{array}{l}\text { Petugas memberikan kesempatan } \\
\text { bertanya kepada pelanggan setelah } \\
\text { proses pemasangan listrik prabayar }\end{array}$ & $78,42 \%$ \\
\hline
\end{tabular}

Sumber : Data primer diolah (2018)

Dari tabel 6 dapat dilihat bahwa perhatian petugas dalam memberikan tutorial singkat menggunakan listrik prabayar memiliki intrepretasi skor $65,13 \%$, petugas bersikap ramah dan sopan memiliki intrepretasi skor $75,53 \%$, kemampuan komunikasi petugas dalam proses pemasangan listrik prabayar memiliki intrepretasi skor $71,25 \%$, petugas tidak memandang status sosial pelanggan dalam memberikan pelayanan optimal memiliki intrepretasi skor $80,87 \%$, kesempatan bertanya yang diberikan petugas kepada pelanggan setelah proses pemasangan listrik prabayar memiliki intrepretasi skor $78,42 \%$.

\section{KESIMPULAN}

Penelitian dilakukan di Area Pelayanan Banyumanik Semarang terhadap 80 responden yang diambil secara acak dan dimintai keterangannya mengenai kualitas pelayanan pemasangan listrik prabayar PT. PLN (persero) Area Pelayanan Banyumanik Semarang. Berdasarkan hasil penelitian yang dilakukan dapat disimpulkan bahwa dimensi yang menunjukkan kualitas pelayanan meliputi tangibles (bukti langsung), reliability (kehandalan), responsiveness (daya tanggap), assurance (jaminan), emphaty (empati) menunjukkan intrepretasi yang kuat dan sangat kuat dimana pelanggan merasa puas terhadap kualitas pelayanan PT. PLN (Persero) Area Pelayanan Banyumanik Semarang.

1. Dari dimensi bukti langsung dapat dilihat penampilan lapangan karyawan memiliki intrepretasi skor $79,99 \%$, kualitas meter listrik pintar yang dipasang memiliki intrepretasi skor $82,16 \%$, kelengkapan peralatan dalam pemasangan listrik prabayar memiliki intrepretasi skor 88, $29 \%$.

2. Dari dimensi kehandalan dapat kita lihat kehandalan petugas dalam pemasangan listrik prabayar memiliki intrepretasi skor $82,42 \%$, kecepatan dan kebaikan yang dilakukan petugas dalam proses pemasangan listrik prabayar memiliki intrepretasi skor 77,86\%, pelayanan sesuai dengan kebutuhan kita atau tidak memiliki intrepretasi skor 70,12\%, keterampilan petugas dalam pemasangan listrik prabayar memiliki intrepretasi skor 78,88\%, ketepatan waktu petugas 4intrepretasi skor $70,28 \%$, kemudahan dan memiliki intrepretasi skor $73,18 \%$.

3. Dari dimensi daya tanggap dapat kita lihat bahwa petugas memberikan informasi yang jelas dan mudah dimengerti mengenai listrik prabayar memiliki intrepretasi skor $80,75 \%$, kecepatan dalam melayani pemasangan listrik prabayar oleh petugas memiliki intrepretasi skor $74,33 \%$, kejelasan dan kemudahan informasi mengenai listrik prabayar memiliki intrepretasi skor $81,00 \%$, kesediaan petugas menolong ketika kita mengalami kesulitan dalam menggunakan listrik prabayar memiliki intrepretasi skor $66,86 \%$, serta perhatian petugas pemasangan listrik prabayar dalam melayani memiliki intrepretasi skor $73,28 \%$.

4. Dari dimensi jaminan dapat kita lihat bahwa apakah petugas selalu memberikan senyum memiliki intrepretasi skor $82,89 \%$, petugas bersikap sopan dan menghormati pelanggan memiliki intrepretasi skor $81,76 \%$, petugas bersikap jujur memiliki intrepretasi skor $88,12 \%$, petugas memberikan penjelasan menggunakan listrik prabayar dengan aman dan benar memiliki intrepretasi skor $81,10 \%$.

5. Dari dimensi empati dapat kita lihat bahwa perhatian petugas dalam memberikan tutorial singkat menggunakan listrik prabayar memiliki intrepretasi skor $65,13 \%$, petugas bersikap ramah dan sopan memiliki intrepretasi skor 75,53\%, kemampuan komunikasi petugas dalam proses pemasangan listrik prabayar memiliki intrepretasi skor $71,25 \%$, petugas tidak memandang status sosial pelanggan dalam memberikan pelayanan optimal memiliki intrepretasi skor 
$80,87 \%$, kesempatan bertanya yang diberikan petugas kepada pelanggan setelah proses pemasangan listrik prabayar memiliki intrepretasi skor $78,42 \%$.

\section{REFERENSI}

Berry, L. L., \& Parasuraman, A. (1990). Delivering Quality Service : Balancing Customer Perceptions and Expectations. The Free Press. New York

Markoni. (2015). Analisis Kepuasan Pelanggan PT. PLN (Persero) Terhadap Proses Pemasangan Listrik Prabayar (Studi Kasus PT. PLN WS2JB Rayon Sukarami). Jurnal Manajemen dan Bisnis Sriwijaya Volume 13 Nomor 4
Nur, Muhammad. (2017). Kualitas Pelayanan Prima pada PT.PLN (Persero) Rayon Makassar Selatan. Jurnal Office Volume 3 Nomor 1

Pasolong, Harbani (2012). Metode Penelitian Administrasi Publik. Alfabeta. Bandung

Sudijono, Anas. (2017). Pengantar Statistik Pendidikan. Rajawali press. Jakarta

Sudiro, Achmad. (2018). Perilaku Organisasi. Bumi Aksara. Jakarta

Sutrisno, Edy. (2015). Budaya Organisasi. Prenadamedia group. Jakarta 